\title{
PERSEPSI HUKUM ADAT LARVUL NGABAL PADA MASYARAKAT KEI PERANTAUAN DI KOTA JAYAPURA PROVINSI PAPUA
}

\author{
Muhamad Yusuf ${ }^{[1]}$, Dewi Nofrita ${ }^{[2]}$, Nanik Nikmal Mafiroh ${ }^{[3]}$, \\ Afan Garamatan $[4]$ \\ ${ }^{[1,3,4]}$ IAIN Fattahul Muluk Papua \\ ${ }^{[2]}$ IAIN Ambon
}

\begin{abstract}
ABSTRAK
Penelitian ini bertujuan untuk mengetahui tentang pemahaman masyarakat Kei perantauan yang ada di kota Jayapura tentang hukum adat Larvul Ngabal, serta dampak dari nilai-nilai hukum adat Larvul Ngabal yang mulai hilang pada masyarakat Kei perantauan yang ada di kota Jayapura. Menggunakan metode kualitatif dengan paradigma fenomenologi sosial. Hasil penelitian: Fenomena yang terjadi pada masyarakat Kei perantauan yang ada di kota Jayapura mengalami degradasi budaya asalnya yaitu budaya Kei, dimana banyak generasi muda Kei terutama yang besar di Kota Jayapura dan yang merupakan orang Kei campuran (salah satu orang tuanya bukan Kei) tidak memiliki kemampuan berbahasa Kei, hal ini mengakibatkan ketidak mampuan untuk menguasai Hukum adat Larvul Ngabal, begitu pula generasi muda yang mampu berbahasa daerah Kei (Veveu Evav) tidak mampu menguasai isi dari hukum tersebut. Di lain sisi, adanya penguatan terhadap unsur agama sehingga menggerus keberadaan hukum adat Larvul Ngabal yang tanpa disadari bahwa hukum adat ini mampu mempersatukan berbagai agama dalam masyarakat Kei. Pertentangan mendasar hanyalah berkaitan dengan sanksi yang diterapkan oleh hukum adat masih dirasakan sangat memberatkan masyarakat Kei, juga ada pendapat bahwa jika budaya Kei dilakukan di daerah rantau maka penggunaan Kasta dalam adat pasti menyeruak kembali.
\end{abstract}

Kata Kunci: Larvul Ngabal, Masyarakat Kei, Perantauan

\section{ABSTRACT}

This study aims to find out about the understanding of the overseas Kei people in the city of Jayapura about the customary law of Larvul Ngabal and the impact of the values of the customary law of Larvul Ngabal which are starting to disappear on the overseas Kei people in 
the city of Jayapura. Using qualitative methods with a social phenomenology paradigm. Research results: The phenomenon that occurs in the overseas Kei community in Jayapura city has experienced a degradation of its original culture, namely the Kei culture, where many of the Kei young generation, especially those who grew up in Jayapura City and who are mixed Kei people (one of their parents is not Kei), cannot speak Kei, this results in an inability to master the customary law of Larvul Ngabal, as well as the younger generation who can speak the Kei area (Veveu Evav) unable to master the contents of the law. On the other hand, there is a strengthening of religious elements so that it erodes the existence of Larvul Ngabal customary law which without realizing that this customary law can unite various religions in the Kei community. The fundamental conflict is only related to the sanctions imposed by customary law which are still very burdensome for the Kei people, there is also an opinion that if the Kei culture is carried out in overseas areas, the use of caste in custom must be reopened.

Keyword: Larvul Ngabal, Kei Community, Overseas

\section{A. PENDAHULUAN}

Indonesia yang merupakan negara kepulauan yang terdiri dari berbagai suku, ras, bahasa, budaya dan agama yang berbeda-beda merupakan salah satu keberagaman dan kekayaan yang tidak dimiliki oleh bangsa lain, yang mampu disatukan dalam satu ikatan kesatuan yaitu Negara Republik Indonesia. Salah satu keberagaman yang menarik adalah masalah budaya, dimana terlahir norma-norma adat yang dimiliki oleh suku-suku tersebut dan dijunjung tinggi keberadaannya sehingga terkadang melahirkan hukum-hukum adat yang mengatur kehidupan dalam bermasyarakat, dan dari tatanan nilai adat istiadat, banyak kebiasaankebiasaan hidup nenek moyang kita yang memiliki nilai-nilai moralitas yang tinggi terhadap citra bangsa, namun tanpa disadari masyarakat Indonesia sudah mulai meninggalkan kebiasaan-kebiasaan baik yang diturunkan oleh para leluhurnya.

Hukum adat merupakan salah satu sumber hukum yang penting dalam rangka pembangunan hukum nasional yang menuju ke arah peraturan perundang-undangan. Unsur-unsur kejiwaan hukum adat yang berintikan kepribadian bangsa Indonesia perlu dimasukkan ke dalam peraturan hukum baru agar hukum yang baru itu sesuai dengan dasar keadilan dan perasaan hukum masyarakat Indonesia.

Masyarakat Kei ${ }^{1}$ yang merupakan salah satu suku yang ada di wilayah negara kesatuan Republik Indonesia, dimana letak wilayahnya berada di Maluku Tenggara yang merupakan daerah kepulauan karang yang berada

${ }^{1}$ Kei merupakan penamaan dari sebuah pulau di wilayah Maluku Tenggara, yang asal katanya terbagi atas 2 penjelasan. 1. Kai Waeid: Tidak Tau yang disebabkan karena komunikasi yang sulit dengan para pendatang baru, 2. Kaios yang dalam bahasa Portugis berarti batu, atau Cayos yang berarti karang atau karang laut (Planten 1892, dalam Renwarin 1983, dalam Resubun, P.I, 2007:2) 
dalam provinsi Maluku, yang juga masyarakatnya memiliki norma-norma adat yang tertuang dalam hukum adat Larvul $\mathrm{Ngabal}^{2}$ yang merupakan dasar pijakan bagi kehidupan, perilaku dan tindakan masyarakat Kei. Orang Kei lebih mirip dengan ras dari Papua, mereka merupakan pelaut ulung dimana mereka sanggup membuat kapal dari zaman dahulu dengan menggunakan bilah-bilah papan dimana sambungannya digunakan pasakpasak yang terbuat dari kayu. mereka lebih banyak mencari nafkah dengan cara menjadi nelayan, dimana sebagian besar wilayahnya adalah tanah karang yang agak sulit dijadikan untuk lahan pertanian. Pada masa pemerintah Hindia Belanda kepulauan Kei berstatus sebagai afdeeling dan termasuk dalam wilayah administrasi pemerintahan Keresidenan Maluku. Pada tahun 1931, wilayah Tual terbagi dalam empat onderafdeeling meliputi; (1) Kepulauan Kei, (2) Kepulauan Aru, (3) Kepulauan Tanimbar, dan (4) Kepulauan Barat Daya.

Kepulauan Kei terdiri dari 2 pulau yaitu Pulau yang agak besar dinamakan Nuhuroa dan pulau yang kecil dinamakan Nuhukut. Orang Kei lebih mirip dengan ras dari Papua 3 . Masyarakat Kei melakukan perjalanan ke tanah Papua diperkirakan dimulai pada tahun 1892 di wilayah Fak-fak dan Manokwari, sedangkan masuk di kota Jayapura yang pada sa'at itu bernama Holandia pada tahun 1910 (Meterai, 2007, hal. 1), mereka melakukan migrasi ke Papua mendampingi penguasa kolonial Belanda dan bekerja sebagai Guru, Tukang Kayu, Suster, Mantri dan lain sebagainya, dengan membawa adat istiadat mereka yaitu hukum Larvul Ngabal ke daerah rantau yaitu tanah Papua. Orang Kei adalah pembuat perahu yang handal ${ }^{4}$, untuk itu tidak heran ketika orang Kei telah sampai ke Papua sejak ratusan tahun yang lalu.

Namun semakin pesatnya perkembangan zaman sa'at ini, jangankan Hukum Larvul Ngabal, bahasa daerah asal pun terkadang tidak dimengerti dan dipahami oleh masyarakat Kai perantauan yang ada di Papua, terlebih yang telah beranak pinak di Provinsi Papua, bahkan yang ada di kota Jayapura.

Penelitian ini bertujuan untuk mengetahui tentang pemahaman masyarakat Kei perantauan yang ada di kota Jayapura tentang hukum adat Larvul Ngabal, serta dampak dari nilai-nilai hukum adat Larvul Ngabal yang mulai hilang pada masyarakat Kei perantauan yang ada di kota Jayapura.

Penelitian terdahulu yang mirip dengan penelitian ini diantaranya, (Ayu, n.d.) mengatakan : Perlindungan hak milik atas tanah "Hawear

${ }^{2}$ Secara Etimologis, pengertian Larvul Ngabal diartikan sebagai berikut: Larvul berarti darah (darah kerbau) dan Ngabal berarti: Tombak Bali. Keduanya dipandang sebagai meterai penerimaan hukum adat. (Ohoitimur, 1996;5).

3 Prilaku mereka keras, cepat dan bersemangat, kulit gelap, rambut keriting, dan yang paling penting wajah mereka berbeda dengan orang Melayu (Wallace, 2015, hal. 608-609)

4Keahlian paling unggul yang dikuasai oleh penduduk asli Kei adalah membuat Kapal, Kano kecil mereka dibuat dengan sangat indah, luas dan rendah ditengah, tetapi meninggi disetiap ujungnya, mereka tidak melubangi kayu pohon untuk membuat perahutersebut, tetapi dibangun dari papan berjalan dari ujung keujung, dan dipasang dengan akurat dan rapat, kapal yang besar berbobot 20 sampai 30 ton, dan siap diluncurkan ke laut tanpa paku atau menggunakan bahan besidan tanpa menggunakan alat lainnya selain kapak dan gurdi (Wallace, 2015, hal. 613-614). 
Balwirin" terhadap tanah adat Larvul Ngabal masyarakat adat Kei di Ohoi (Desa) Wain Kecamatan Kei Kecil Timur Maluku Tenggara belum maksimal. Faktor yang menyebabkan masyarakat adat Kei melakukan perlindungan hak milik atas tanah karena tanah yang diwarisiturun temurun menjadi tempat untuk pemukiman, perkebunan, serta bercocok tanam. Bentuk perlindingan yang diberikan yaitu Sasi Hawear.

Perbedaan yang jelas dalam penelitian tersebut diatas adalah peneliti melakukan penelitian di wilayah kota Jayapura terhadap masyarakat Kei yang ada di kota tersebut, dengan menggunakan berbagai teori diantaranya Simbol, Agama, teori tentang Nilai, Difusi dan lain sebagainya yang mendukung penelitian.

Hukum Larvul Ngabal merupakan hukum adat yang dimiliki oleh masyarakat kepulauan Kei Maluku Tenggara, yang tidak tergantung pada otoritas negara, Ia hanya berlaku untuk masyarakat adat, baik yang ada di kepulauan Kei bahkan terkadang dilakukan pula oleh masyarakat Kei yang ada di perantauan. Dari pendekatan historis dan budaya Von Savigny dan Eungen Ehrlich (Cotterrell \& Cotterrell, 1992, hal. 34) mengelompokan fenomena hukum seperti itu sebagai "The Living Law" (hukum yang hidup dalam masyarakat) yang berasal dari kenyataan sosial dan tidak tergantung pada otoritas negara.

Hukum Larvul Ngabal disebut juga sebagai dasar pijakan bagi masyarakat Kei dalam kehidupan sehari-hari, baik yang berkaitan dengan perilaku, tindakan, orang Kei. Renwarin (Resubun, 2007, hal. 7) menyajikan dua versi kisah pemunculannya sebagai berikut. Pertama : Orang yang paling berpengaruh adalah Raja Tebtut dari Ohoivur yang terletak diantara desa Letvuan dan Evu di selat Sorbai (Kei Kecil). Berabad-abad muncul leluhur Tebtut bernama Dewa dari Bali. Dewa menurunkan Fadiersamaai, yang kemudian menikah dan mendapat seorang anak yang diberi nama Tetbut dan kemudian Ia diangkat menjadi Raja Ohoivur. Ia menunjuk Arnuhu sebagai Raja Danar dan Wain. Ia menyebut Ursiwa dan meterai pengangkatannya Larvul, yang berarti berhenti menumpahkan darah, tidak membunuh atau melukai orang dan juga tidak menyihir sesama. Jika orang melanggar hukum/peraturan, maka harus membayar denda berupa mas atau barang berharga lainnya. Kemudian Tebtut mengangkat raja Sangli di Rumat5, Ia memberi hukum dan aturan yang sama. Sebagai meterai pengangkatannya Ia menerima sebuah pedang dan sebuah pohon yang diberi nama Ngabal.

Sedangkan versi kedua mengisahkan bahwa pada suatu ketika Tebtut mengunjungi Bali. Dari sana Ia membawa sebuah tombak dan sebuah pedang. Ia mengirim tombak ke Lair-Ohoilim (Kei Besar) ${ }^{6}$ untuk mengikat perjanjian dengan mereka, yaitu Lorlim (ikatan 5 desa). Para bawahannya harus mematuhi hukum yang dibawa olehnya. Sedangkan Lorsiw lahir dari putri Tebtut, yakni Ditsakmas dan suaminya Arnuhu (Danar) yang memotong kerbau dan membagikan dagingnya diantara 9 desa.

Kei.

5Letvuan, Danar, Rumat, merupakan nama-nama kampung/desa yang ada di kepulauan

${ }^{6}$ Lair-Ohoilim (Kei Besar) merupakan salahsatu pulau (pulau terbesar) yang ada di kepulauan Kei. 
Cerita Larvul Ngabal merupakan produk budaya yang menyampaikan sejumlah pesan budaya berkaitan dengan filosofi, sistem kepercayaan, dan norma-norma hukum komunitas masyarakat Kei. Secara substantif, cerita Larvul Ngabal adalah suatu genre sastra lisan, yakni cerita rakyat yang dianggap sakral oleh orang Kei dan diyakini benar-benar terjadi pada waktu lampau memiliki bentuk, makna-fungsi dan pemertahanan yang dituturkan secara unik dan spesifik. Namun di daerah asal hukum ini masih juga dilaksanakan dalam beberapa bentuk kegiatan adat misal: kegiatan penjualan tanah, pelantikan kepala kampung dan sebagainya.

Sedangkan penggunaan istilah Larvul diambil dari kata Lar yang artinya "Darah" dan kata Vul dapat diartikan "Merah". Adapun kata Lar : Darah, berasal dari darah Kerbau Hukum Larvul ini sudah menetapkan garis-garis besar peraturan hukum dan tata tertib yang wajib diikuti oleh semua masyarakat $E v v^{7}$ guna keamanan, kebaikan dan kerukunan hidup hingga lazimnya dikatakan "Larvul Enturak" maksudnya menggaris bataskan hukum. Sedangkan Ngabal diambil dari kata Nga yang artinya : Tombak dan Bal diarikan sebagai Bali. Hukum Ngabal ini menyaring garisgaris besar peraturan, tata tertib yang lebih rinci, supaya lebih dimiliki, gampang diikuti, dan senang ditaati oleh masyarakat. Para leluhur biasa menyebutnya Ngabal Enadung yang artinya : Hukum Ngabal yang nyaring. berikut :

Hukum adat Larvul Ngabal terdiri atas beberapa bagian yaitu sebagai

Bagian I biasa disebut dengan pembukaan berisi tentang :

1. Rat nesno, umas enba : Raja bertitah, pengawal melaksanakan;

2. Lem yau warsa, yau waro : Keputusan dan sansi hanya atas dasar kebenaran dan keadilan;

3. Loor tel sa, yaing reng infit fatel : Perbuatan melanggar hukum secara kongkrit diatur menurut hukum adat Larvul Ngabal yag tertuang dalam hukum Nevnev, Hanilit, dan Hawear Balwirin.

Bagian Ke II berisi isi pokok hukum Larvul Ngabal yang terdiri atas :

1. Hukum Nevnev (Hukum yang mengatur hak hidup manusia);

2. Hukum Hanilit (Hukum tentang kesusilaan/moral);

3. Hukum Hawear Balwirin (Tentang hak atas milik) (Resubun, 2007, hal. 8-9).

Bagian ke III dalam hukum adat Larvul Ngabal berisi tentang Sasa sor fit ${ }^{8}$ yaitu bagian-bagian yang dilarang dalam setiap hukum tersebut.

1. Sasa sor fit Hukum Navnev.

2. Sasa sor fit Hukum Hanilit

7Evav/Ewav atau Ewab, kata ini berasal dari kata ai : kayu dan vav yang berarti babi, C.Bossher seperti dikutip Renwarin (Resubun, 2007, hal. 2), menyebutkan bahwa pulau-pulau Kei pada waktu itu menghasilkan berbagai jenis kayu yang bagus kualitasnya: "Ik ben ervan overtuigd dat er nog vele andere houtsoorten zijn, want ik geloof niet dat er in deze gehele archipel een eiland te vinden is, zo rijk aan bossen als Groot en Klein Kei”. Sedangkan G.W Baron van Hoevell menulis bahwa babi merupakan binatang kesayangan bagi orang kei pada waktu itu. Bahkan mereka menamakan pulau mereka pulau Babi, Zo ook noemden zij zelve hun eilanden "Varkeneilanden" (Ewav of Ewab), Renwarin (Resubun, 2007, hal. 2)

${ }^{8}$ Sasa atau sa berarti salah atau kesalahan, sor berarti helai, bagian atau lapisan, dan fit berarti tujuh. Jadi yang dimaksud dengan sasa sor fit adalah kesalahan yang berlapis tujuh atau kesalahan yang terdiri dari tujuh bagian dan bertentangan dengan hukum Larvul Ngabal (Resubun, 2007, hal. 9) 
3. Sasa sor fit Hukum Hawear Balwarin. (Resubun, 2007, hal. 9-10)

Bagian ke IV biasa disebut penutup yang berisi tentang :

1. Adat nabletang hormat : ketaatan terhadap adat, menjunjung tinggi kehormatan dan martabat manusia;

2. Ntuuh suntub raam, fo enreek naa vuam yatam : simpanlah hukum Larvul Ngabal dalam lubuk hatimu dan menopang jantung hatimu;

3. Taha fo vusin manan, nti ntut wahan enhaar naa soin : kesetiaan melakukan hukum adat Larvul Ngabal dengan teguh sampai akhir hayat.

Dengan adanya Sasa sor fit ini, orang dengan mudah dapat menentukan tindakan yang melanggar hukum Larvul Ngabal, sehingga mudah untuk menetapkan hukumannya. Ketentuan umum berlaku demikian, dimana Sasa sor fit hukum Nevnev yang tidak menyebabkan kematian, hukumannya diputuskan oleh sidang adat, sedangkan pembunuhan didenda dengan ganti jiwa yang kemudian dilaksanakan dengan tebusan harta denda yang disebut Vut wau dan vuut faak. Pelanggaran terhadap hukum Hanilit telah ditetapkan dengan tegas dan orang tinggal mengikutinya (Y.Ohoitimur, 1996, hal. 20)

Hukum adat yang ada dalam masyarakat Kei merupakan Mores, dimana melanggar mores merupakan satu tantangan bagi masyarakat adat. Seperti halnya yang dikatakan Summer (Roucek dkk., 1984, hal. 28) mengatakan bahwa :

1. Ia selalu betul dan penentuan betul dan salah adalah didefinisikan oleh mores;

2. Ia menunjukkan satu tegangan kearah penetapan antara satu sama lain;

3. Mores tidak takut pada pengawasan secara rasional;

4. Mores berubah secara mendadak sejalan dengan perubahan kondisi hidup.

Masyarakat Kei mengartikan hukum adat Larvur Ngabal yang diambil dari kata: Larvul dimana kata Lar yang artinya "Darah" dan kata Vul dapat diartikan "Merah". Adapun kata Lar : Darah, berasal dari darah Kerbau Hukum Larvul ini sudah menetapkan garis-garis besar peraturan hukum dan tata tertib yang wajib diikuti oleh semua masyarakat Evav guna keamanan, kebaikan dan kerukunan hidup hingga lazimnya dikatakan "Larvul Enturak" maksudnya menggaris bataskan hukum. Sedangkan Ngabal diambil dari kata Nga yang artinya : Tombak dan Bal diarikan sebagai Bali. Hukum Ngabal ini menyaring garis-garis besar peraturan, tata tertib yang lebih rinci, supaya lebih dimiliki, gampang diikuti, dan senang ditaati oleh masyarakat. Para leluhur biasa menyebutnya Ngabal Enadung yang artinya : Hukum Ngabal yang nyaring.

Makna dari cerita Larvul Ngabal yang tertuang diatas mencerminkan pandangan hidup orang Kei yang mengandung konsepsi mendalam dan gagasan mengenai wujud kehidupan mengenai hubungan manusia dan alam baik secara vertikal antara manusia dengan Tuhan, hubungan horisontal antara manusia dengan manusia dan hubungan sirkular-harmonis antara manusia dengan alam semesta sebagai suatu totalitas dari sikap hidup orang Kei yang tercermin dalam makna filosofis, makna religis, makna kosmologis, 
dan makna mistis. Ceritera tentang asal muasal Larvul Ngabal merupakan mitos $^{9}$ turun temurun dari masyarakat Kei yang semakin lama semakin memudar akibat dari tidak tertuangnya ceritera tersebut dalam tulisan.

Fungsi cerita Larvul Ngabal mengarah pada: fungsi sosiologis, fungsi pedagogis, fungsi yuridis. Fungsi sosiologis diimplementasikan sebagai sarana pengungkap asal-usul, sebagai pengungkap struktur sosial masyarakat Kei, dan sebagai sarana untuk memperkenalkan sistem pemerintahan baru. Fungsi pedagogis mengukuhkan cerita Larvul Ngabal sebagai model pendidikan etis moral, ajaran tentang pembaharuan, mengajarkan bahasa simbolik. Sedangkan fungsi yuridis, cerita larvul merupakan hukum yang mengatur ketentuan tentang masalah pidana maupun perdata.

Penelitian yang dilakukan ini merupakan penelitian deskriptip kualitatif. Suharsimi Arikunto (Mayalibit \& Yusuf, 2020, hal. 38) mengatakan : Metode dalam penelitian kualitatif lebih pada penegasan dan penjelasan yang menunjuk pada prosedur-prosedur umum seperti alasan (1) pendekatan tersebut digunakan (2) unit analisis (3) metode pengumpulan data dan (4) keabsahan data.

Penggunaan logika berfikir inter subjektifitas ${ }^{10}$, yang dimulai dari penggunaan teori, pengumpulan informasi melalui wawancara, observasi dan lain sebagainya kemudian melakukan pertanyaan-pertanyaan terbuka, menganalisis data berdasarkan tema-tema dan kategori-kategori, melanjutkan dengan mencari pola-pola umum, teori-teori dari tema-tema atau kategori-kategori yang dibuat, kemudian mengemukakan generalisasi atau teori dari literatur atau pengalaman pribadi. Paradigma penelitian kualitatif yang digunakan adalah: Fenomenologis Sosial. Dijelaskan oleh Schutz dan Luckmann (Nawir dkk., 2020, hal. 161):”Fenomenologi Sosial dimaksudkan untuk merumuskan ilmu sosial yang mampu 'menafsirkan dan menjelaskan tindakan dan pemikiran manusia' dengan cara menggambarkan struktur-struktur dasar"....realita yang tampak 'nyata' dimata setiap orang yang berpegang teguh pada 'sikap alamiah', dengan model Studi Kasus yang intrinsik. Intrinsic case Study Jenis ini ditempuh oleh peneliti yang ingin memahami sebuah kasus tertentu. (Denzin \& Lincoln, 2000, hal. 301) Penelitian ini memusatkan perhatian pada makna dan pengalaman subjektif sehari-hari, yang bertujuan untuk menjelaskan bagaimana objek dan pengalaman tercipta secara penuh makna dan dikomunikasikan dalam kehidupan sehari-hari.

Jenis dan sumber data, sumber data yang digunakan dalam penelitian ini adalah data primer dan skunder. Data primer adalah data yang langsung dikumpulkan peneliti dari sumber pertamanya dengan cara memperoleh informan atau subyek yang akan diteliti, yaitu masyarakat Kei di kota Jayapura. Data sekunder adalah data yang tersusun dalam bentuk dokumen

${ }^{9}$ Mitos merupakan suatu warisan bentuk cerita tertentu, tradisi lisan yang mengisahkan dewa-dewa, manusia pertama, binatang-binatang, dan sebagainya, berdasarkan suatu skema logis yang terkandung didalam cerita mitos itudan yang memungkinkan kita mengintegrasikan segala problem yang perlu diselesaikan dalam suatu konstruksi sistematis (Levi-Strauss, 1997, hal. 150).

${ }^{10}$ Secara umum menciptakan makna dan realitas antara peneliti dan partisipan. (Norman K. Denzin \& Yvonna S. Lincoln (Nawir dkk., 2020, hal. 161)) 
atau buku, jurnal, majalah ilmiah yang diperoleh dari pusat studi kepustakaan yang berhubungan dengan obyek yang diteliti. Seting penelitian dilakukan di wilayah Kota Madya Daerah Tingkat II Jayapura. Dengan instrumen kunci penelitian adalah keluarga yang merupakan orang turunan maupun yang asli Kei yang tinggal dan menetap di daerah tersebut.

Guna mendapatkan data lapangan, yaitu antara lain : Pertama dengan melakukan observasi partisipatoris. Dalam kegiatan observasi partisipatoris ini, yaitu penulis berusaha melakukan kegiatan pemuatan perhatian terhadap sesuatu obyek dengan seluruh panca indra tentang gejala-gejala tertentu dengan jalan mengamati langsung sehingga peneliti mengenal langsung obyek yang diteliti. Dalam hal ini peneliti terlibat langsung dengan kegiatan penelitian di wilayah Kota Jayapura, dan peneliti berpartisipasi dalam kegiatan penelitian tersebut. Yang kedua dengan melakukan in-depth interview. Kedalaman wawancara yang dilakukan oleh penulis adalah dialog atau wawancara untuk memperoleh data yang akan diteliti yang didapat dari informan atau nara sumber, dengan lebih bebas, untuk mendapatkan permasalahan lebih terbuka, dengan melakukan wawancara tidak berstruktur. Identitas informan, waktu penelitian dituliskan dalam penelitian ini. Berikut dengan melakukan studi dokumentasi. Yaitu penulis berusaha untuk mencari sumber data yang akan diteliti dari buku-buku, dokumen, peraturan-peran yang mendukung dalam penelitian, baik berupa catatan harian, gambar atau karya-karya monumental dari seseorang.

Menggunakan tehnik analisa model Miles dan Huberman (Yusuf dkk., 2020, hal. 276), yang menganalisa data dengan membagi kedalam tiga bagian, yaitu : Pertama dengan melakukan Reduksi Data : Yaitu merangkum data, memilih hal-hal yang pokok, memfokuskan pada hal-hal yang penting, dan membuang hal-hal yang tidak diperlukan; Kedua dengan melakukan data Display (Penyajian Data) : Yaitu membuat uraian singkat, bagan, hubungan antar kategori dan sejenisnya; dan yang terakhir melakukan Conclusion Drawing/verification : Yaitu penarikan kesimpulan dan verifikasi.

\section{B. PEMAHAMAN MASYARAKAT KEI TENTANG HUKUM ADAT LARVUL NGABAL}

\section{Pemahaman Tentang Hukum Larvul Ngabal}

Hukum Larvul Ngabal disebut juga sebagai dasar pijakan bagi masyarakat Kei dalam kehidupan sehari-hari, baik yang berkaitan dengan perilaku, dan tindakan, orang Kei dalam bermasyarakat. Namun banyak juga masyarakat Kei yang ada di kota Jayapura tidak memahami isi dari hukum tersebut.

Istilah hukum adat adalah terjemahan dari istilah bahasa Belanda: adatrecht dan kata adat berasal dari bahasa Arab, yang berarti: kebiasaan (Muhammad, Bushar, 2006, hal. 1-3). Hukum adat diartikan sebagai hukum non-statutar yang sebagian besar adalah hukum kebiasaan. Hukum adat berakar pada kebudayaan tradisional. Hukum 
adat adalah suatu hukum yang hidup, karena ia menjelmakan perasaan hukum yang nyata dari rakyat (Soepomo, 2007, hal. 3). Lebih lanjut (Soepomo, 2007, hal. 21) mengatakan bahwa: Hukum adat yang tradisional menunjukkan adanya nilai-nilai universal seperti asas gotong royong, fungsi sosial manusia,dan milik dalam masyarakat, asas persetujuan sebagai kekuasaan umum, asas perwakilan dan permusyawaratan dalam sistim pemerintahan.

Masyarakat Kei perantauan yang mengerti tentang isi dari hukum tersebut, terutama bagi generasi sekarang ini yang besar di Papua, terlebih bagi mereka yang lahir dan besar di Papua atau yang bukan orang asli Kei (yang hanya salah satu orang tuanya orang Kei). Dapat dikatakan pula bahwa : bagaimana mungkin orang Kei perantauan yang ada di kota Jayapura dapat memahami isi dari hukum tersebut jika bahasa Kei saja banyak yang tidak mengetahuinya.

\section{Hukum Larvul Ngabal Yang Dilupakan Generasi Sekarang}

Pemahaman tentang Budaya Adat masyarakat Kei yang dilahirkan oleh leluhurnya banyak yang dilupakan oleh masyarakat Kei itu sendiri, terlebih yang ada di perantauan seperti: masyarakat Kei yang ada di Kota Jayapura. Hal ini dapat menimbulkan krisis budaya bagi masyarakat Kei perantauan, terlebih yang bagi mereka yang lahir dan besar didaerah perantauan dan belum sekalipun pulang kedaerah asal leluhurnya.

Generasi muda Kei sa'at ini yang ada di kota Jayapura, banyak yang tidak memahami isi dari Hukum adat masyarakat Kei yaitu hukum Larvul Ngabal. Hal ini disebabkan oleh banyak faktor, diantaranya : heterogenitas kota Jayapura, yang menyebabkan melemahnya penggunaan bahasa daerah baik dikalangan masyarakat Kei, sehingga menyebabkan kesulitan untuk mengartikan hukum Larvul Ngabal itu sendiri, juga karena kurangnya penekanan dari keluarga besar masyarakat Kei se Kota Jayapura tentang sosialisasi hukum adat yang ada di masyarakat Kei, walaupun pelaksanaan dari ancaman hukuman tidak dilaksanakan, namun sedikit banyak warga Kei perantauan tau akan budayanya, sehingga budaya tersebut tetap lestari.

\section{PERSEPSI MASYARAKAT KEI TENTANG KEBERADAAN HUKUM LARVUL NGABAL}

\section{Pendapat Orang Kei Di Kota Jayapura Tentang Hukum Larvul Ngabal}

Pandangan orang Kei yang ada di kota Jayapura tentang hukum Larvul Ngabal sangat berbeda-beda, terlebih antara orang-orang Tua yang pernah hidup di kampung halaman dengan kaum Muda, yang memahami isi kandungan hukum Larvul Ngabal dengan yang tidak mengerti isi kandungan hukum tersebut, dan yang lahir dan besar di kampung halaman dengan yang sejak lahir atupun besar di Jayapura. Sehingga menimbulkan kesulitan dalam pengembangan budaya hukum Larvul Ngabal pada masyarakat Kei perantauan di kota Jayapura. 
Hukum adat diartikan sebagai hukum non-statutar yang sebagian besar adalah hukum kebiasaan. Hukum adat berakar pada kebudayaan tradisional

Terdapat perbedaan pandangan diantara masyarakat adat Kei yang ada di kota Jayapura, ada yang acuh tak acuh terhadap hukum tersebut. Namun ada pula yang menginginkan hukum tersebut sebagai budaya yang perlu untuk dilestarikan sehingga tidak hilang walaupun berada diperantauan, sehingga menimbulkan rasa persaudaraan yang tinggi diantara sesama masyarakat Kei di kota Jayapura, seperti kata pepatah Kei yang berbunyi: "Manut enmehe ni tilur, fuut enmehe ni ngifun", yang artinya: telur-telur yang berasal dari seekor ikan dan seekor burung yang sama", atau diartikan bahwa: Masyarakat Kei berasal dari satu moyang yang sama. Itulah pepatah adat orang Kei yang sering terdengar sampai sa'at ini, sehingga mampu memperkokoh rasa persaudaraan, persatuan, tidak menjadikan hidup diperantauan sendirisendiri sehingga dapat mewujudkan pepatah: "Ain taba ain $i$ enru, ain enhov ain akbo vangled" (satu tambah satu sama dengan dua, dan satu dengan satu menjadi banyak).

\section{Kemunculan Agama dan Pengaruhnya Terhadap Keberadaan Hukum Larvul Ngabal}

Agama-agama besar yang ada di kepulauan Kei Maluku Tenggara muncul belakangan setelah hukum adat tersebut dicetuskan, yang dibawa oleh para pendatang dari luar kepulauan Kei, dimana masyarakat Kei pada sa'at itu masih memeluk agama leluhurnya. Namun lambat laun bergeser dan pindah ke agama-agama yang dibawa oleh para pendatang tersebut.

Namun, semakin berkembangnya agama-agama besar yaitu Islam, Katholik dan Protestan di wilayah kepulauan Kei, ada perjanjian adat/diktum yang terkadang orang Kei sendiri lupa bahwa yang berbunyi sebagai berikut : "Agam ni bavilun adat" (agama berlandaskan pada adat) (Topatimasang Roem dan Laksono P.M, 2004, hal. 99) yang lambat laun hilang dengan sendirinya dengan daya takluk yang sangat kuat dari masing-masing agama besar tersebut, yang mampu mempengaruhi masyarakat Kei sehingga meninggalkan adat leluhurnya.

Isi hukum Larvul Ngabal memang telah ada dalam agama, namun sangsi terhadap larangan hukum tersebut yang memang tidak terdapat dalam ajaran agama manapun, hal itu karena Hukum adat muncul biasanya atas dasar kesepakatan bersama dari masyarakat tradisional. Namun sangatlah miris jika hukum adat tersebut lenyap akibat dari munculnya agama yang mengekang hkum adat, dimana seharusnya mampu berjalan beriringan.

Emile Durkheim (Turner, 2012, hal. 694-695) menjelaskan tentang sosiologi agama yang berkaitan dengan kesucian sebagai berikut: "Semua agama mengklasifikasikan kesucian-segala hal yang dikesampingkan dan dilarang-dan keduniawian, dan hal yang dianggap suci tidak melekat dalam sesuatu itu sendiri namun ditentukan demikian oleh masyarakat tertentu. Sesuatu menjadi suci jika terdapat perasaan 
bersama yang dilekatkan kepadanya. Karena manusia atau alam tidak suci dengan sendirinya, sifat kesucian itu pasti datang dari sumber lain., dan sumber itu adalah masyarakat. Maka, adalah persatuan dan keberagaman kehidupan sosial yang menciptakan baik persatuan dan keberagaman dari mahluk dan benda-benda yang suci.

Dikatakan Durkheim (Turner, 2012, hal. 698), mengatakan bahwa: Agama akan tetap menjadi suatu fakta sosial, suatu kenyataan sosial yang tidak dapat disangkal oleh ilmu pengetahuan, dengan kata lain agama akan beradaptasi dan mengubah dirinya sendiri dan tidak akan menghilang. Durkeim memandang bahwa: agama atau yang suci sebagai sesuatu yang mengharuskan orang untuk berkumpul bertindak secara bersama-sama (sehingga menyesuaikan dorongan perorangan dengan kekuatan moral atau sosial bersama), dan sebagai sesuatu konsekwensi yang diperkuat melalui kemampuan perorangan dan bersama dalam menghadapi kegembiraan dan kesedihan kehidupan sehari-hari.

Agama secara perlahan tapi pasti menggeser kedudukan hukum adat Larvul Ngabal, akan tetapi harus disadari bahwa pertikaian yang disebabkan oleh agama-agama besar yang pecah di daerah Maluku pada tahun 1999 mampu diredam dalam waktu yang singkat di wilayah Kei Maluku Tenggara berkat Hukum adat Larvul Ngabal yang mampu mempersatukan kembali masyarakat Kei yang bertikai pada sa'at itu. Dengan demikian sangat disayangkan jika Hukum Larvul Ngabal tersebut hilang didaerah perantauan dikarenakan agama, sebab pada sa'at munculnya agama-agama besar dan berkembang di kepulauan Kei telah ada kesepakatan yang telah disebutkan diatas bahwa: "Agam ni bavilun adat" (agama berlandaskan pada adat). Antara adat dan agama merupakan satu kesatuan yang tidak dapat dipisah-pisahkan, ataupun salah satu diantaranya harus ditinggalkan.

\section{KEMAMPUAN MASYARAKAT KEI DALAM MENERAPKAN BAHASA DAERAHNYA}

Bahasa merupakan alat pemersatu suatu bangsa, suku, yang ada di muka bumi ini. Tanpa adanya bahasa sulit kiranya bagi manusia untuk melakukan komunikasi antara sesamanya. Indonesia merupakan negara yang kaya akan bahasa daerah, karena memiliki beratus-ratus bahasa daerah yang antara satu dengan lainnya memiliki perbedaan, dan ciri tersendiri.

Akankah bahasa-bahasa daerah ini mampu untuk tetap hidup danlestari sangatlah tergantung dari orang-orang/suku-suku yang ada di Nusantara ini untuk dapat melestarikannya. Begitu pula bahasa Kei, yang ada di kepulauan Kei Maluku Tenggara, dalam menyikapi keberadaan bahasa daerahnya sebagai aset budaya bangsa. 


\section{Bahasa Daerah Sebagai Alat Pemersatu}

Alat pemersatu masyarakat Kei baik yang ada di daerah asalnya ataupun yang ada di daerah perantauan adalah bahasa. Bahasa percakapan secara umum yang digunakan masyarakat Kei adalah bahasa Kei (Veveu Evav) ${ }^{11}$, adalah bahasa yang paling luas pemakaiannya di kepulauan Kei, walaupun ada bahasa Kur (Veveu Kuur), Bahasa Banda ${ }^{12}$ (Viveu Wadan), namun bahasa keseharian untuk menyatukan masyarakat Kei adalah bahasa Kei (Veveu Evav), dengan induk yang sama yaitu bahasa Kei Fordata ${ }^{13}$. Pada sa'at ini penggunaan bahasa Kei jarang dilakukan oleh generasi muda Kei terlebih yang ada di perantauan apalagi yang bukan orang Kei asli (Keturunan, yang salah satu orang tuanya asli Kei).

Dengan tidak adanya penekanan pada kemampuan berbahasa daerah, lambat laun bahasa daerah Kei akan hilang di daerah perantauan hal tersebut disebabkan oleh heterogenitas masyarakat kota Jayapura, sehingga penggunaan bahasa daerah Kei dirasakan kurang efektif dalam bersosialisasi dengan masyarakat lainnya, sehingga mereka lebih mengedepankan bahasa Indonesia sebagai bahasa sehari-hari, bahkan bahasa Indonesia diterapkan pula pada sa'at di rumah.

Penggunaan bahasa daerah Kei di Kota Jayapura semakin jarang ditemui dikalangan generasi muda terlebih bagi mereka yang lahir dan besar di Papua juga bagi mereka yang hanya salah satu dari kedua orang tuanya adalah orang Kei, hal ini disebabkan karena tidak adanya penekanan penggunaan bahasa daerah di rumah. Namun juga disebabkan karena masyarakat Kei tidak ingin karena bahasa menimbulkan ketersinggungan masyarakat lain dalam bersosialisasi. Sehingga bahasa daerah tersebut tidak berkembang di daerah perantauan seperti di kota Jayapura. Hal inilah yang menyebabkan banyak generasi muda Kei yang ada di kota Jayapura tidak mampu berbahasa daerah. Sehingga dapat dikatakan bahwa bagaimana mungkin dapat mempersatukan adat orang Kei (Adat Evav baletan dunyai), di perantauan seperti di kota Jayapura jika banyak orang Kei sendiri yang tidak mampu berbahasa Kei. Kei Besar

${ }^{11}$ Merupakan bahasa yang paling banyak digunakan, yakni di 207 desa di Kei Kecil dan

${ }^{12}$ Keberadaan orang Banda di Kepulauan Kei awalnya adalah para pelarian dari banda untuk menghindari pembantaian masal, pada tahun 1621 yang dilakukan oleh Gubernur Jenderal Hindia Belanda, Jan Pieters Zoon Coen, dalam rangka memaksa penduduk Banda menyerahkan tanah mereka untuk diubah menjadi lahan perkebunan pala (Topatimasang Roem dan Laksono P.M, 2004, hal. 83)

13Dalam peta kebahasaan oleh The Australian Institute for Humanities, seluruh bahasa atau dialek lokal kepulauan Kei memang berasal dari satu sumber, yakni bahasa 'Kei Fordata' (Fordata adalah pulau kecil diantara kepulauan Kei dengan kepulauan Tanimbar, dekat dengan pulau kecil Tanimbar Kei-sehingga bahasa Tanimbar Kei dianggap sebagai ragam lokal bahasa Kei yang paling ,mendekati ragam asli bahasa Kei Fordata tersebut), dalam satu rumpun besar (phylum) bahasa-bahasa Austronesia (Topatimasang Roem dan Laksono P.M, 2004, hal. 83). 


\section{Kemampuan Masyarakat Kei Di Kota Jayapura Dalam Penguasaan Tiga Bahasa Kei Sekaligus}

Sudah dijelaskan sebelumnya bahwa bahasa yang ada di kepulauan Kei mencakup tiga bahasa rumpun, yang masing-masing rumpun memiliki perbedaan pada $\operatorname{Rim}^{14}$ nya. Sehingga tidak semua orang mampu untuk menggunakan 3 bahasa secara sekaligus. Masyarakat Kei perantauan yang tinggal di Kota Jayapura yang tidak mampu menguasai bahasa Kei secara keseluruhan, hal ini disebabkan karena dialek dari bahasa tersebut yang dianggap sulit. Bahasa-bahasa tersebut hanya mampu dilakukan oleh orang-orang tertentu saja, misalkan orang Tua-tua, orang Banda eli atau banda Elat, Kur yang besar di Kei dan pindah ke Jayapura. Tetapi orang Banda Eli atau Banda Elat, dan orang Kur yang besar di Jayapura sejak lahir dan memiliki salah satu orang tuanya yang bukan dari Kei pun banyak yang tidak mampu untuk berbahasa Veveu Evav, terlebih bahasa asal mereka.

\section{Penggunaan Simbol Tombak Dan Darah Dalam Pengertian Hukum Larvul Ngabal}

Untuk menerangkan suatu kebudayaan dibutuhkan adanya teoriteori simbol, dimana simbol-simbol itu membentuk kebudayaan. Seperti halnya masyarakat Kei menggunakan simbol-simbol kedaerahan dalam menyatukan masyarakatnya yang tertuang dalam hokum adat Larvul Ngabal.

(Geertz, 1992, hal. 22) mengatakan bahwa : Apapun dan dimanapun juga, mungkin ada sistem-sistem simbol "dalam pengertianpengertian mereka sendiri”, lebih lanjut dikatakan oleh G.H. Mead dan pakar-pakar lainnya dalam (Geertz, 1992, hal. 56) mengatakan bahwa; Sebagian besar simbol-simbol itu adalah kata-kata, tapi juga isyaratisyarat, lukisan-lukisan, bunyi-bunyian musik, peralatan mekanis seperti jam-jam, atau objek alamiah seperti permata. Lebih lanjut dikatakan oleh Clifford Geertz (Jenks, 2013, hal. 88) mengatakan bahwa: Pendekatan Mentalik simboliknya, banyak mengandalkan pada deskripsi tentang sesuatu yang dipandangnya sebagai lapis-lapis mediasi, seperti suasana hati, motivasi dan konsepsi., antara system-sistem symbolsimbol dan berbagai faktualitas kehidupan sehari-hari. Mary Douglas dalam V.W. Dillistone (Nawir dkk., 2020, hal. 109) mengungkapkan : Natural Symbols memberikan kesaksian tentang nilai dari corak tertentu bentuk-bentuk ritual dalam membawakan koherensi dan stabilitas kepada masyarakat, kedudukan dan batas disimbolkan dengan tepat oleh ciri-ciri tubuh.

Penggunaan tombak dan darah merupakan simbol yang memiliki arti penting bagi masyarakat Kei dimana memiliki corak tertentu dalam mempertahankan stabilitas masyarakat Kei, dan merupakan objek isyarat yang mengacu pada suatu objek tindakan yang harus dilakukan masyarakat Kei yang tertuang dalam hokum adat masyarakat Kei.

14Rim: merupakan tekanan-tekanan nada berbicara/dialektik/fonem yang ada pada setiap bahasa di kepulauan Kei. 


\section{E. NILAI DAN NORMA ADAT YANG MASIH BERTAHAN}

Nilai merupakan suatu pola normatif, yang menentukan tingkah laku yang diinginkan bagi suatu sistem yang ada kaitannya dengan lingkungan sekitar tanpa membedakan fungsi-fungsi bagiannya. (Wijaya, 1993, hal. 19) mengatakan bahwa : "Nilai adalah : Sifat/hal yang penting/berguna bagi kemanusiaan, sesuatu yang paling didambakan, sesuatu yang ingin dicapai, sesuatu yang dimulyakan atau dikagumi, kualitas atau fakta, sesuatu itu amat baik, bermanfaat dan diinginkan". Lebih lanjut dijelaskan bahwa: "guna nilai adalah sebagai sumber dantujuan pedoman hidup manusia"

Sedangkan yang dimaksud dengan Norma adalah Norma adalah perintah yang tidak personal dan anonim (an impersonal and anonymous "command" - that is the norm), norma dapat pula diartikan sebagai: Suatu perangkat agar hubungan di dalam suatu masyarakat terlaksana sebagaimana yang diharapkan. Norma-norma mengalami proses pelembagaan atau melewati suatu norma kemasyarakatan yang baru untuk menjadi bagian dari salah satu lembaga masyarakat sehingga norma tersebut dikenal, diakui, dihargai, dan kemudian ditaati dalam kehidupan sehari-hari. (Wijaya, 1993, hal. 19) mengatakan bahwa: "Norma adalah ukuran, suatu aturan atau pola suatu tindakan, pedoman yang mengatur tingkah laku masyarakat, standart pertimbangan, penjabaran dari nilai.

Dalam hukum adat Larvul Ngabal terdapat nilai-nilai yang merupakan inti dari moral, dimana didalmnya diajarkan tentang kebaikankebaikan, yang sangat bermanfaat dalam kehidupan bermasyarakat.

Ada tujuh bagian dalam setiap isi dari setiap bagian hukum yang disebut Sasa sor fit yaitu bagian-bagian yang dilarang dalam setiap hukum tersebut, dimana sudah dijelaskan pada bab I. Pada bagian ini terdapat larangan-larangan bagi orang Kei dalam hidup bermasyarakat.

Isi dari hukum-hukum tersebut jika kita membaca kembali pada bab sebelumnya tidak ada perbedaan dengan apa yang diajarkan oleh agama. Namun tanpa disadari bersama larangan-larangan tersebut terkadang tidak dilaksanakan oleh orang Kei itu sendiri, tetapi ada juga yang mampu dilaksanakan tanpa mengetahui isi dari hukum tersebut.

Agama yang berbeda-beda dalam masyarakat Kei rentan menimbulkan perselisihan, namun berkat adanya hukum adat, yang kemunculannya sebelum datangnya agama-agama dari luar, perpecahan tersebut dapat diatasi/diredam. Sebagai contoh pertikaian besar yang pernah terjadi diseluruh tanah Maluku, masyarakat Kei lah yang mampu lebih dulu menuntaskannya dengan hukum adat Larvul Ngabal.

Isi dari hukum Larvul Ngabal telah termuat dalam hukum agama, dimana dalam Islam disebut Syaksiyah termuat dalam Al-Qur'an dan Hadits Nabi Muhammad S.A.W, begitu pula dalam agama Nasrani, terdapat dalam 10 perintah Tuhan (The Ten commandments) yang dibawa Musa A.S dan dilanjutkan oleh Isa A.S. Dengan demikian dapat dikatakan bahwa : Bagi orang Kei yang melanggar hukum agama berarti juga secara tidak langsung, tahu ataupun tidak tahu tentang isi dari hukum adat Larvul Ngabal dapat dikatakan melanggar hukum adat Larvul Ngabal. Sehingga dapat dikatakan pula bahwa nilai dan norma yang ada dalam hukum Larvul Ngabal juga ada dalam hukum Agama itu sendiri, dan dilaksanakan oleh setiap penganut 
agama tersebut. Untuk itu maka dapat dikatakan bahwa : Nilai-nilai yang terkandung dalam Norma Hukum Adat Larvul Ngabal masih dijankan oleh masyarakat Kei perantauan khususnya yang ada di wilayah kota Jayapura melalui hukum-hukum yang tertera dalam agamanya masing-masing.

\section{F. NORMA HUKUM ADAT YANG MULAI HILANG}

Dari tatanan nilai adat istiadat, banyak kebiasaan-kebiasaan hidup nenek moyang kita yang memiliki nilai-nilai moralitas yang tinggi terhadap citra bangsa, namun tanpa disadari masyarakat Indonesia sudah mulai meninggalkan kebiasaan-kebiasaan baik yang diturunkan oleh para leluhurnya. Misalkan mengenai hal-hal yang tabu yang dilarang untuk dilanggar, contoh: mencuri, berbuat onar, tidak memberikan penghormatan kepada yang lebih dituakan, tidak sopan dalam berbicara, dan lain sebagainya, yang dipandang oleh generasi kapanpun adalah sesuatu yang baik dan harus terus dilestarikan. Sepanjang suatu adat istiadat dan budaya itu memberikan peluang untuk tumbuh dan berkembangnya prakarsa yang baik, hendaknya sebagai generasi penerus harus tetap melestarikannya.

Norma adat yang tercantum dalam butir-butir hukum Larvul Ngabal ada beberapa yang sudah mulai pudar.hal ini akibat dari degradasi mental generasi muda masyarakat Kei terlebih dalam era globalisasi sekarang ini. Tidak dapat dipungkiri, bahwa apa yang dijelaskan tersebut benar adanya hal ini disebabkan pula oleh pengaruh Westernisasi yang melanda generasi muda saat ini, bukan saja masyarakat Kei perantauan yang ada di kota Jayapura tapi juga masyarakat pendatang lainnya yang ada di kota Jayapura dan bahkan di kota-kota lainnya. Ini memerlukan penanganan yang serius dari berbagai pihak guna mengatasi krisis moral bangsa melalui pendekatak agama dan pendekatan budaya bangsa agar nilai-nilai yang terkandung dalam norma adat khususnya bagi masyarakat Kei di kota Jayapura tidak meninggalkan norma adatnya dengan mengaplikasikan Hukum adat Larvul Ngabal dalam kehidupan bermasyarakat, sehingga dapat hidup aman damai dan tentram di wilayah kota Jayapura.

\section{G. KESIMPULAN}

Adapun fenomena yang terjadi pada masyarakat Kei perantauan yang ada di kota Jayapura mengalami degradasi budaya asalnya yaitu budaya Kei, dimana banyak generasi muda Kei terutama yang besar di Kota Jayapura dan yang merupakan orang Kei campuran (salah satu orang tuanya bukan Kei) tidak memiliki kemampuan berbahasa Kei, hal ini mengakibatkan ketidak mampuan untuk menguasai Hukum adat Larvul Ngabal, begitu pula generasi muda yang mampu berbahasa daerah Kei (Veveu Evav) tidak mampu pula menguasai isi dari hukum tersebut. Dengan demikian bagaimana mungkin dapat melestarikan hukum adat Larvul Ngabal di Kota Jayapura. Di lain sisi, adanya penguatan terhadap unsur agama sehingga menggerus keberadaan hukum adat Larvul Ngabal yang tanpa disadari bahwa budaya adat ini mampu mempersatukan berbagai agama dalam 
masyarakat Kei. Pertentangan mendasar hanyalah berkaitan dengan sanksi yang diterapkan oleh hukum adat masih dirasakan sangat memberatkan masyarakat Kei, juga ada pendapat bahwa jika budaya Kei dilakukan di daerah rantau maka penggunaan Kasta dalam adat pasti menyeruak kembali. Namun tanpa disadari ada beberapa norma adat yang mulai hilang dikalangan generasi muda Kei yang ada di kota Jayapura yang paling nampak adalah terletak pada beberapa poin yang ada dalam hukum Hanilit (hak kehormatan dan martabat kaum wanita), yang dirasa mulai kurang dihargai.

Saran-saran yang dapat dikemukakan sebagai berikut. Hendaknya pemuka adat masyarakat Kei yang ada di kota Jayapura lebih menekankan penggunaan bahasa Kei (Veveu Evav) dalam setiap kegiatan kedaerahan, dan lebih menekankan kepada keluarga Kei agar mengedepankan bahasa daerahnya, agar hukum adat lebih mudah untuk dimengerti, dipahami dan dilaksanakan tanpa harus mengedepankan sanksi, untuk dapat mempersatukan adat orang Kei (Adat Evav baletan dunyai). Hukum adat Larvul Ngabal yang merupakan Snib teteen (perjanjian para leluhur), hendaknya selalu dijaga dan disesuaikan dengan agama masing-masing, sehingga "Agam ni bavilun adat" (agama berlandaskan pada adat), hal ini telah terbukti dalam meredam kerusuhan yang terjadi di kepulauan Kei daerah Maluku Tenggara. Ini merupakan kombinasi cara yang terbaik (the best combination) antara hukum adat dengan agama dan merupakan cita rasa keseimbangan (sense of equilibrium) antara hukum adat dan agama. Hukum adat dapat menimbulkan efek dongkrak (laverage effect) terhadap pegembangan mental yang menghasilkan moral generasi muda Kei di kota Jayapura lebih baik lagi. sehingga persatuan dan kesatuan antar sesama masyarakat Kei dapat lebih diperkokoh dan dipererat seperti dalam pepatah Kei :"Ain taba ain $i$ enru, ain enhov ain akbo vangled" (satu tambah satu sama dengan dua, dan satu dengan satu menjadi banyak).dan dalam rangka mewujudkan pepatah Kei lainnya yang berbunyi "Manut enmehe ni tilur, fuut enmehe ni ngifun”, yang artinya : telur-telur yang berasal dari seekor ikan dan seekor burung yang sama atau dapat diartikan bahwa masyarakat Kei berasal dari moyang yang sama”.

\section{REFERENSI}

\section{Buku}

Cotterrell, R. B. M., \& Cotterrell, R. (1992). The Sociology Of Law: An Introduction. Oxford University Press.

Denzin, N. K., \& Lincoln, Y. S. (2000). Introduction: The Discipline And Practice Of Qualitative Research. In Handbook Of Qualitative Research (2nd Edition).

Geertz, C. (1992). Tafsir Kebudayaan. Penerbit Kanisius.

Jenks, C. (2013). Culture Studi Kebudayaan. Yogyakarta: Pustaka Pelajar. 
Levi-Strauss, C. (1997). Mitos Dukun Dan Sihir. Terjemahan Drs. Agus Cremers, Svc Dan Drs. De Santoso Johanes. Yogyakarta: Kanisius.

Muhammad, Bushar, P. S. H. (2006). Asas- Asas Hukum Adat: Suatu Pengantar. Pradnya Paramita.

Roucek, J. S., Simamora, S., \& Warren, R. L. (1984). Pengantar Sosiologi. Jakarta: Bina Aksara.

Soepomo, R. (2007). Bab-Bab Tentang Hukum Adat, Cet 17. Jakarta: Pradnya Paramita.

Topatimasang Roem Dan Laksono P.M. (2004). Ken Sa Fak, Benih-Benih Perdamaian Dari Kepulauan Kei. Insist Press.

Turner, B. S. (2012). Teori Sosiologi Dari Klasik Sampai Postmodern. Pustaka Pelajar.

Wallace, A. R. (2015). Sejarah Nusantara: The Malay Archipelago. Yogyakarta: Indolitersi Group.

Wijaya, A. (1993). Etika Administrasi Negara. Bumi Aksara.

\section{Jurnal dan lainnya}

Ayu, Bumi. (2017). Perlindungan Hukum Hak Milik Atas Tanah "Hawear Balwirina" Terhadap Tanah Adat Larvul Ngabal Masyarakat Adat Kei Di Ohoi (Desa) Wain Kecamatan Kei Kecil Timur Kabupaten Maluku Tenggara. Gloria Yuris: Jurnal Hukum Untan, 5 (2). Retrieved from https://jurnal.untan.ac.id/index.php/jmfh/article/view/18262

Mayalibit, M. Y. U. ., \& Yusuf, M. . (2020). Pemahaman Nilai-Nilai Ajaran Islam Di Kampung Samate Kepulauan Raja Ampat. POROS ONIM: Jurnal Sosial Keagamaan, 1 (1), 31-48. Retrieved from http://ejournal.iainfmpapua.ac.id/index.php/porosonim/article/view/27.

Meterai, J. (2007). Ekologi Fisik Dan Budaya Spesifik Papua, Dimana Bumi Dipijak Disitu Langit Dijunjung, Makalah Seminar Budaya Kilas Balik Orang Kei Di Tanah Papua, Eksistensi Dan Peran Serta Orang Kei Dalam Membangun Papua.

Nawir, M. S., Yusuf, M., \& Kadir, A. (2020). Islam Raja Ampat dan Mitos Hantu Cuwig. SANGKéP: Jurnal Kajian Sosial Keagamaan, 3 (1), 1-22. https://doi.org/10.20414/sangkep.v3i1.1482

Resubun, P. (2007). No Title. Beberapa Sikap Hidup Orang Kei, Makalah Seminar Budaya Kilas Balik Orang Kei Di Tanah Papua, Eksistensi Dan Peran Serta Orang Kei Dalam Membangun Papua.

Y.Ohoitimur. (1996). Hukum Adat Dan Sikap Hidup Orang Kei, Dalam Seri Mitra No. 1, Manado Kelompok Studi Communicanda Skolastikal Msc Pineleng.

Yusuf, M. Y., Bugis, A., Iribaram, S., \& Pratiwi, D. (2020). The Rise Of Children Dropping Out Of School In Raja Ampat. Al-Ishlah: Jurnal Pendidikan, 12(2), 270-287. https://doi.org/10.35445/alishlah.v12i2.225 